\title{
Reaching a Consensus on the Definition of Genetic Literacy that Is Required from a Twenty-First-Century Citizen
}

\author{
Dirk Jan Boerwinkel ${ }^{1}$ • Anat Yarden $^{2}$. \\ Arend Jan Waarlo ${ }^{1}$ \\ Published online: 9 November 2017 \\ (C) The Author(s) 2017. This article is an open access publication
}

\begin{abstract}
To determine what knowledge of genetics is needed for decision-making on geneticrelated issues, a consensus-reaching approach was used. An international group of 57 experts, involved in teaching, studying, or developing genetic education and communication or working with genetic applications in medicine, agriculture, or forensics, answered the questions: "What knowledge of genetics is relevant to those individuals not professionally involved in science?" and "Why is this knowledge relevant?" The answers were classified in different knowledge components following the PISA 2015 science framework. During a workshop with the participants, the results were discussed and applied to seven cases in which genetic knowledge is relevant for decision-making. The analysis of these discussions resulted in a revised framework consisting of nine conceptual knowledge components, three sociocultural components, and four epistemic components. The framework can be used in curricular decisions; its open character allows for including new technologies and applications and facilitates comparisons of different cases.
\end{abstract}

\section{Introduction}

Genetics has evolved from a unique subdiscipline of biology into an integral part of most biological research, covering multiple levels of biological organization. Results from studies in genetics influence societal practices, such as disease diagnosis and treatment, drug development,

Dirk Jan Boerwinkel

D.J.Boerwinkel@uu.nl

Anat Yarden

Anat.yarden@weizmann.ac.il

Arend Jan Waarlo

A.J.Waarlo@uu.nl

1 Freudenthal Institute for Science and Mathematics Education, Utrecht University, Utrecht, The Netherlands

2 Weizmann Institute of Science, Rehovot, Israel 
industrial production, forensic investigation, crop protection, and sports. It has also become clear that many genes interact to produce phenotypes, that gene expression is modulated by the environment, and that the path from gene to trait is more complex than previously thought. Thus, images of genes and genomes have changed fundamentally, and the time might come when personal genome analysis will become standard practice (Gelbart 2012). Nevertheless, few of these developments are addressed in biology education: The gap between scientific understanding of genetics and what is taught in genetic education in schools has increased (Dougherty et al. 2011). In recent years, calls for initiatives to improve the public's genetic literacy have emerged, because it is becoming essential for today's citizens (Christensen et al. 2010; Dougherty 2009). Accordingly, teaching and learning materials on bioinformatics, DNA microarray, genetic testing, and forensic DNA research have begun to be developed and implemented (e.g., Machluf and Yarden 2013; Campbell et al. 2006; Van Mil et al. 2010). The question is whether it is sufficient and feasible to simply add new contents to current genetic education or whether a more fundamental restructuring is necessary. To provide an appropiate account of genetics for our future citizens, this study is aimed at defining the term genetic literacy.

Genetic literacy is a part of scientific literacy, which has many definitions. Functional scientific literacy is characterized by the ability to converse, read, and write coherently in a nontechnical but meaningful context (Laugksch 2000). A functional illiterate person, according to Shamos (1995), lacks an understanding of the fundamental role played by theories in the practice of science and of the unique processes that characterize it. In addition, the "true" scientifically literate individual has the ability to use those scientific ways of thinking for individual and social purposes. Few articles have been written on genetic literacy for every citizen. And most literature on genetic literacy concerns health issues. Some studies have addressed the problem of insufficient preparation of healthcare providers to deal with geneticrelated issues (Houwink et al. 2012; Kaye and Korf 2013). McInerney (2002) stressed that prevention in health issues implies a partnership between providers and patients, which means that both health professionals and the public should be sufficiently literate in genetics. Jennings (2004) saw genetic literacy as a part of genetic-literate citizenship which includes both participation in societal deliberation on genetic-related issues and personal decision-making on the use of genetic-related services. Other studies describe genetic literacy more generally, focusing mainly on the undergraduate level (Bowling et al. 2008). Formulating the required genetic literacy to participate as a citizen in today's society has consequences for policy that determines the core curriculum (Dougherty et al. 2011) and on public science communication (Pearson and Liu-Thompkins 2012). The research question investigated in this study is which genetic knowledge is needed for decision-making on genetic-related issues. Toward this end, we conducted a study combining a Delphi approach and a workshop. Delphi studies have proven to be effective in defining and solving curricular questions (Osborne et al. 2003; Bolte 2008). By asking for the genetic knowledge needed for decision-making, this study fits a conception that can be termed functional scientific literacy (Shamos 1995; Laugksch 2000).

\section{Method}

\subsection{Phase I (December 2012)}

Using a consensus-reaching process, experts worked together on a definition for the term "genetic literacy." The initial phase of this study included two questions that were sent to 
experts via e-mail: "What knowledge of genetics is relevant to those individuals not professionally involved in science?" and "Why is this knowledge relevant?" The experts $(n=57)$ included science education researchers $(n=26)$, developers of educational materials $(n=18)$, teachers and teacher educators $(n=8)$, science communicators $(n=6)$, scientists - including medical geneticists, community geneticists, and genetic counseling experts - forensic science experts and agricultural experts $(n=8)$, and educational policy-makers $(n=3)$. The science education researchers and developers were all involved in research and development of genetic education. The total number of experts exceeds 57 because some of the experts had more than a single expertise. To obtain a representative group of participants, we started with a group of researchers from eight different countries who had published on genetic education and asked them to recommend other researchers, developers, teacher educators, and genetic specialists. Participants came mainly from Europe and the USA, along with three participants from Australia and one from Taiwan (Appendix 1).

All participating experts' answers to the first question were initially classified into three types of knowledge, following the PISA 2015 Science Framework (OECD 2016): conceptual knowledge, epistemic knowledge, and procedural knowledge.

The components previously suggested for a learning progression in modern genetics by Duncan et al. (2009) proved useful as a framework to analyze the answers classified under conceptual knowledge. The Duncan et al. (2009) framework is based on the suggestion of Stewart et al. (2005) that knowledge of three integrated conceptual models is necessary to truly understand genetic phenomena: (i) the genetic model, which deals with the patterns of inheritance observed when organisms reproduce sexually and the probabilities with which different patterns are likely to occur; (ii) the meiotic model, which relates to the cellular processes underlying gene recombination, sorting, and transfer from one generation to the next; and (iii) the molecular model, which deals with the mechanisms that link genes to their biological outcomes. The framework of Duncan et al. (2009) expanded these three models to include the environment as the context in which genetic processes take place and emphasized the role of proteins in the development of traits. We found the eight components listed in Duncan et al.'s (2009) suggested framework useful for classifying the answers of the conceptual knowledge type. Responses that could not be classified into any of the components of the framework (see Table 1) were listed separately. The answers that were classified under procedural knowledge and epistemic knowledge were each analyzed bottom-up, allowing the categories to emerge from the data. This process resulted in three tables of knowledge components which were used in the second phase of the study (see Tables 1, 2, and 3).

\subsection{Phase II (March 2013)}

The second phase of the study differed from a traditional Delphi approach in the sense that the participants were no longer anonymous, but met in a workshop to discuss the results of phase I. One week before this workshop, the results of the first phase of the study were e-mailed to all participants. The workshop was attended by 46 out of the 57 experts who responded to the initial survey, plus an additional 8 experts from the local hosting university, who did not participate in the first phase of the study. During the workshop, the experts worked in groups, and each group discussed a different case study in which genetic knowledge is relevant for decision-making. Participants could choose which case they wanted to discuss. Each group was asked to indicate the specific knowledge type - among the three types of knowledge mentioned above — needed to make an informed decision in their specific case. The cases were 
Table 1 The conceptual knowledge components of genetic literacy after the first and second phases of the study. Main changes to Duncan et al.'s (2009) suggested components are indicated by italics. The number of times a category was identified in the experts' answers appears in square brackets

Knowledge components after the first phase

A. All organisms have genetic information that is hierarchically organized

B. The genetic information contains universal instructions that specify protein structure

C. Proteins have a central role in the functioning of all living organisms and are the mechanism that connects genes and traits

D. All cells have the same genetic information, but different cells use (express) different genes

E. Organisms reproduce by transferring their genetic information to the next generation

F. There are patterns of correlation between genes and traits, and there are certain probabilities with which these patterns occur

G. Changes to the genetic information can cause changes in how we look and function

H. Environmental factors can interact with our genetic information

Additional categories

I. Difference between somatic and germ line

J. Evolution and natural selection

K. Polygenic inheritance
Knowledge components after the second phase

1. All organisms have genetic information in their DNA molecules [32]

2. Part of the organism's DNA molecules contains genes. Genes are instructions for the cell to make proteins. These instructions are present in a genetic code that is almost universal in all life [35]

3. Proteins have a central role in the structure and function of all living organisms and form the main mechanisms that connect genes and traits [20]

4. Most cells of an organism have genetic information for all structures and functions, but different genes are switched on and off in different cells [9]

5. During reproduction, organisms transfer their genetic information to the next generation through their reproductive cells. Each parent contributes a set of genes, leading to a double set in the offspring [32]

6. In simple gene-trait relationships, there are patterns of correlation between genes and traits, and there are certain probabilities with which these patterns occur [26]

7. Changes that occur in the genetic information can cause changes in how organisms look and function. Only changes in cells that become gametes are hereditary [40]

8. Individuals of the same species have mostly the same genetic information. Only a small portion of the genetic information accounts for the variation between individuals [20]

9. Multiple genes and multiple environmental factors interact in the development of most traits [37]

Included in 7

Not included

Included in 9

selected to cover a broad spectrum of those that citizens might encounter in their everyday lives. Cases were selected from the main social practices in which genetic applications play a role in today's society: medical diagnosis, food production, sports, and forensics. Another criterion for selecting cases was to cover different gene-trait relationships: monogenic versus polygenic traits, traits with little versus big environmental influence, germline mutations versus somatic mutations, and functional genes versus short tandem repeats. A third criterion for selecting cases was to cover different sources of genetic information, such as the media,

Table 2 The sociocultural knowledge components of genetic literacy after the second phase

Knowledge component

- Genetic technologies used in societal contexts

- Practices in which genetic technology is applied

- Personal and societal implications 
Table 3 The epistemic knowledge components of genetic literacy after the fourth phase

Knowledge component

- Certainty and uncertainty of genetic information

- History of development of genetic knowledge

- (Mis)representation of genetic knowledge in the media

- Identifying and weighing arguments in decision-making

product information, and genetic counseling. Finally, a fourth criterion was to cover different types of societal or personal issues, such as privacy, ethnicity, and health issues. A description of the seven cases is given in Appendix 2.

The cases included

a. Participating in a forensic survey.

b. Testing athletes for sickle cell anemia.

c. Buying genetically modified food.

d. Buying a "direct-to-consumer" genetic test for BRCA-1.

e. Discussing media headlines on a newly found "gene for alcoholism."

f. Participating in a discussion on ethnic ("racial") differences.

g. Genetic counseling for spinal muscular atrophy.

\subsection{Phase III (June 2014)}

The comments of the participants, both on the proposed categorization of knowledge components and on the specific knowledge per case, formed the input for the third phase. In this phase, the first two authors revised the categorization into four types of knowledge:

1. Conceptual: knowledge of genetic concepts.

2. Sociocultural: knowledge of applications of genetic technologies and their implications.

3. Epistemic: knowledge of the meaning of genetic information.

4. Procedural: knowledge on how to use genetic knowledge in communication and decisionmaking.

Expert answers from the first phase were reclassified according to the new categories. Based on the group reports in the second phase, within each knowledge type, a further analysis was performed to identify which specific knowledge was needed in each case. This process resulted in three tables with matrices that describe the content of a specific knowledge component for every case. Each row in Tables 4, 5, and 6 addresses a different part of the specific knowledge component, and each column discusses a different case, providing the specific genetic knowledge needed for decision-making for that knowledge component in each row.

\subsection{Phase IV (November 2015)}

The matrices were sent back to the participants for the final round of comments, producing the final elaboration of genetic literacy required by a twenty-first-century citizen. In this phase, 


\begin{tabular}{|c|c|c|}
\hline 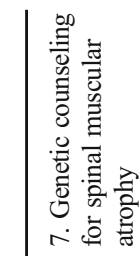 & 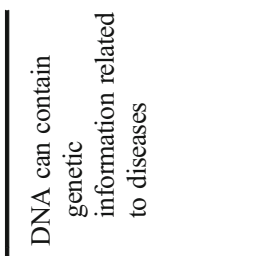 & 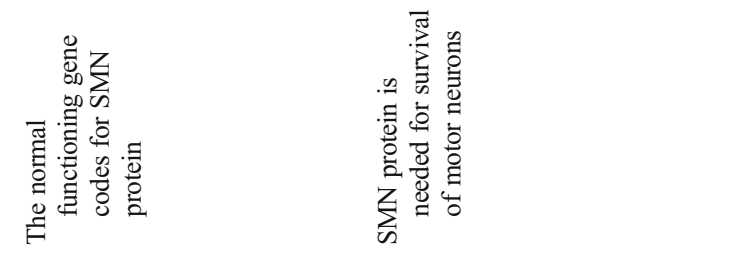 \\
\hline 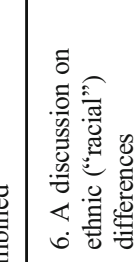 & 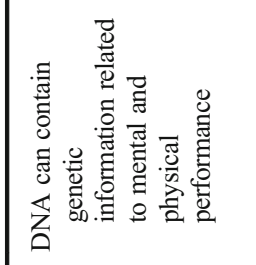 & 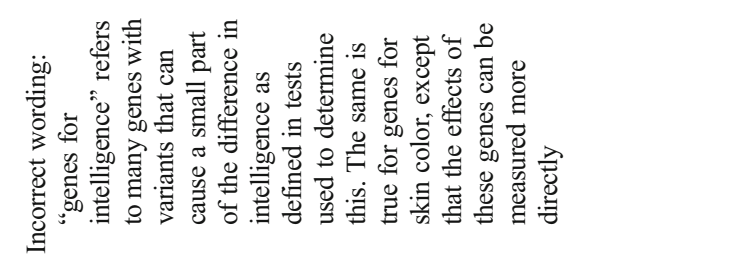 \\
\hline 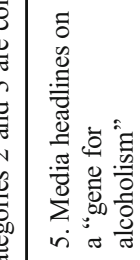 & 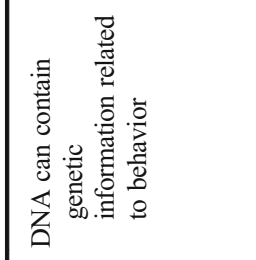 & 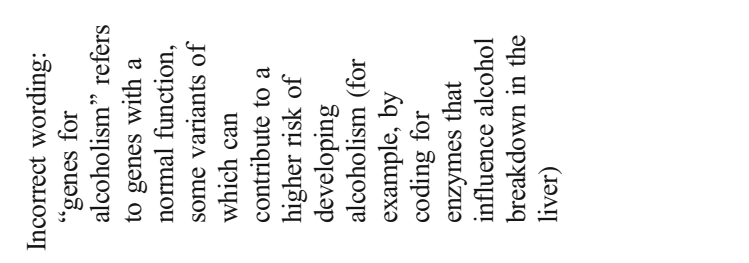 \\
\hline 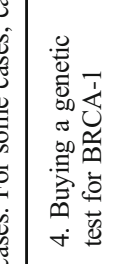 & 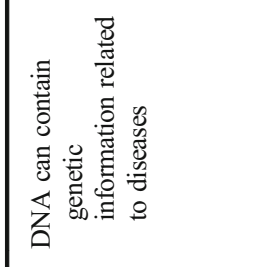 & 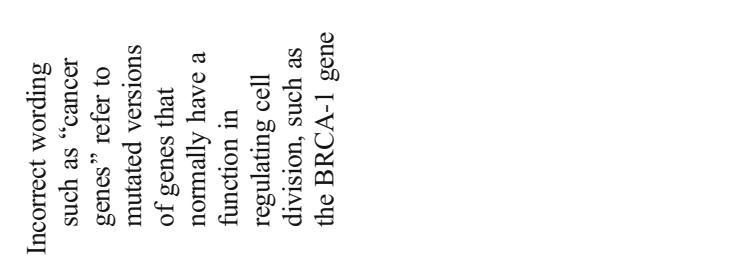 \\
\hline 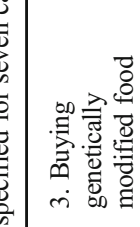 & 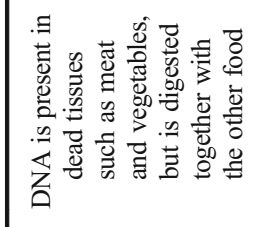 & 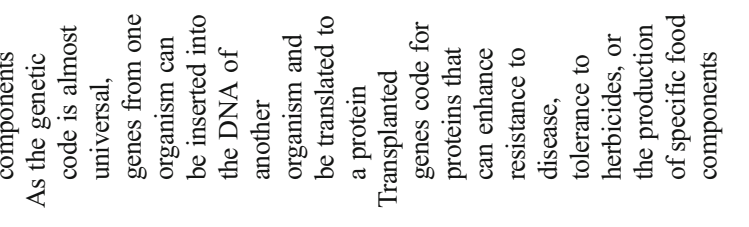 \\
\hline 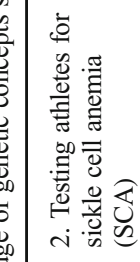 & 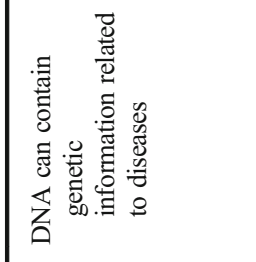 & 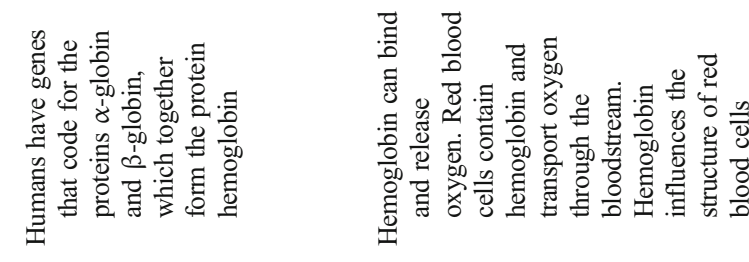 \\
\hline 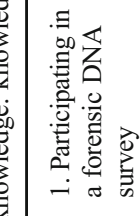 & 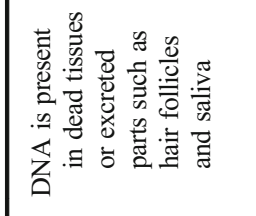 & 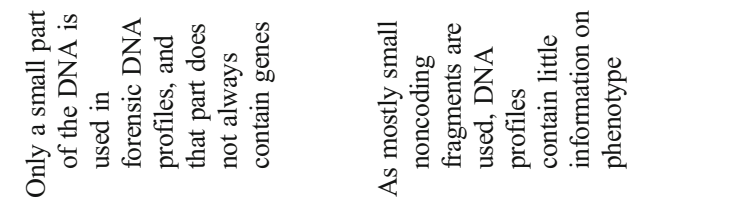 \\
\hline 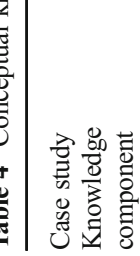 & 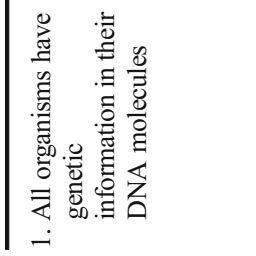 & 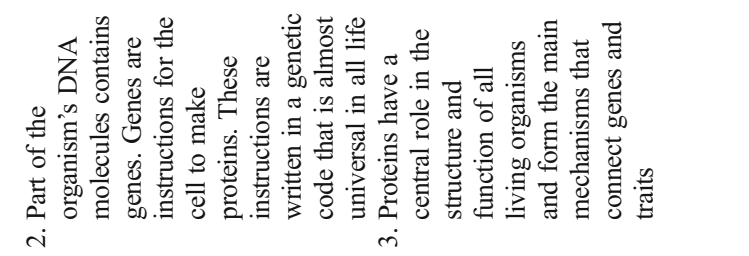 \\
\hline
\end{tabular}




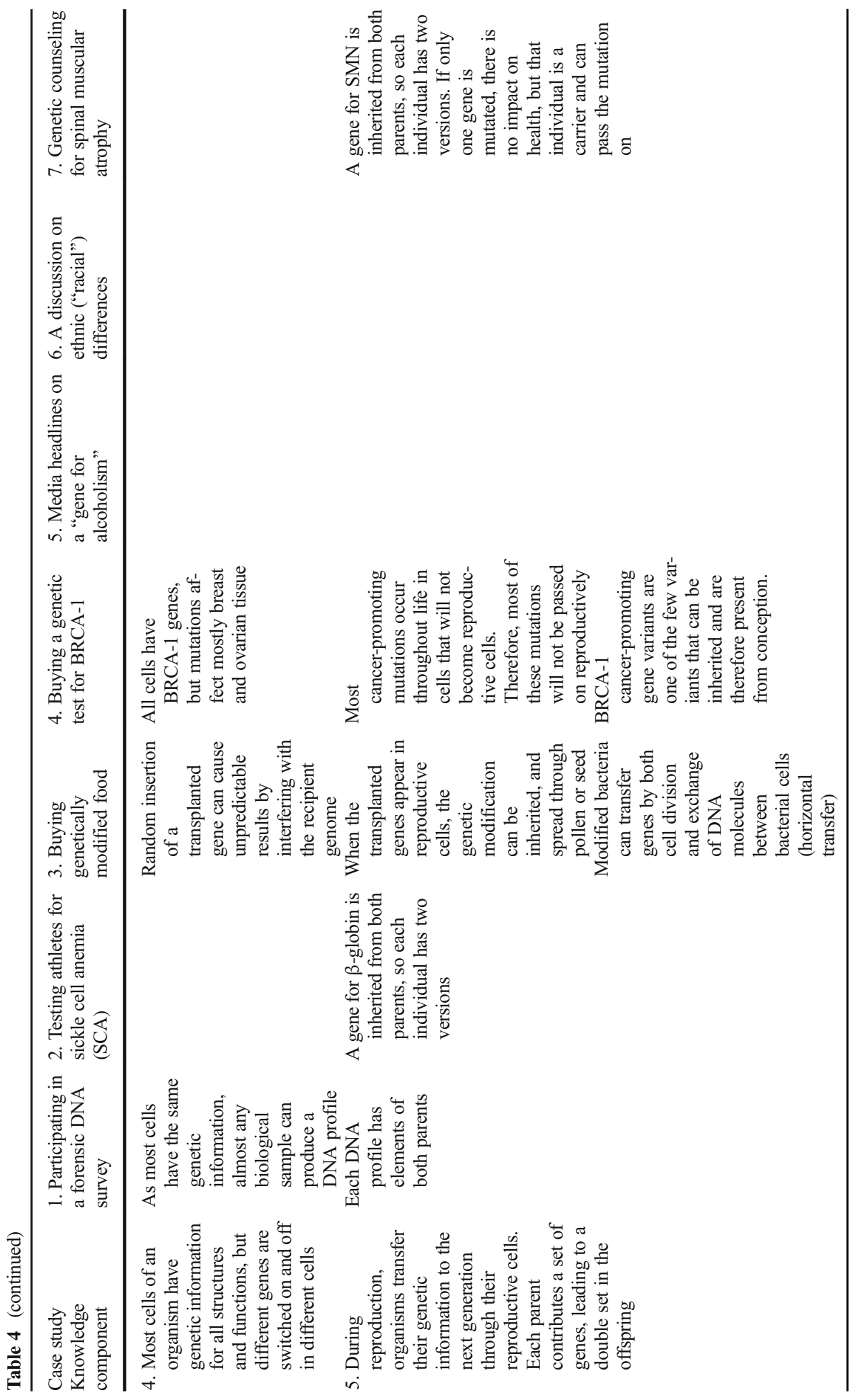




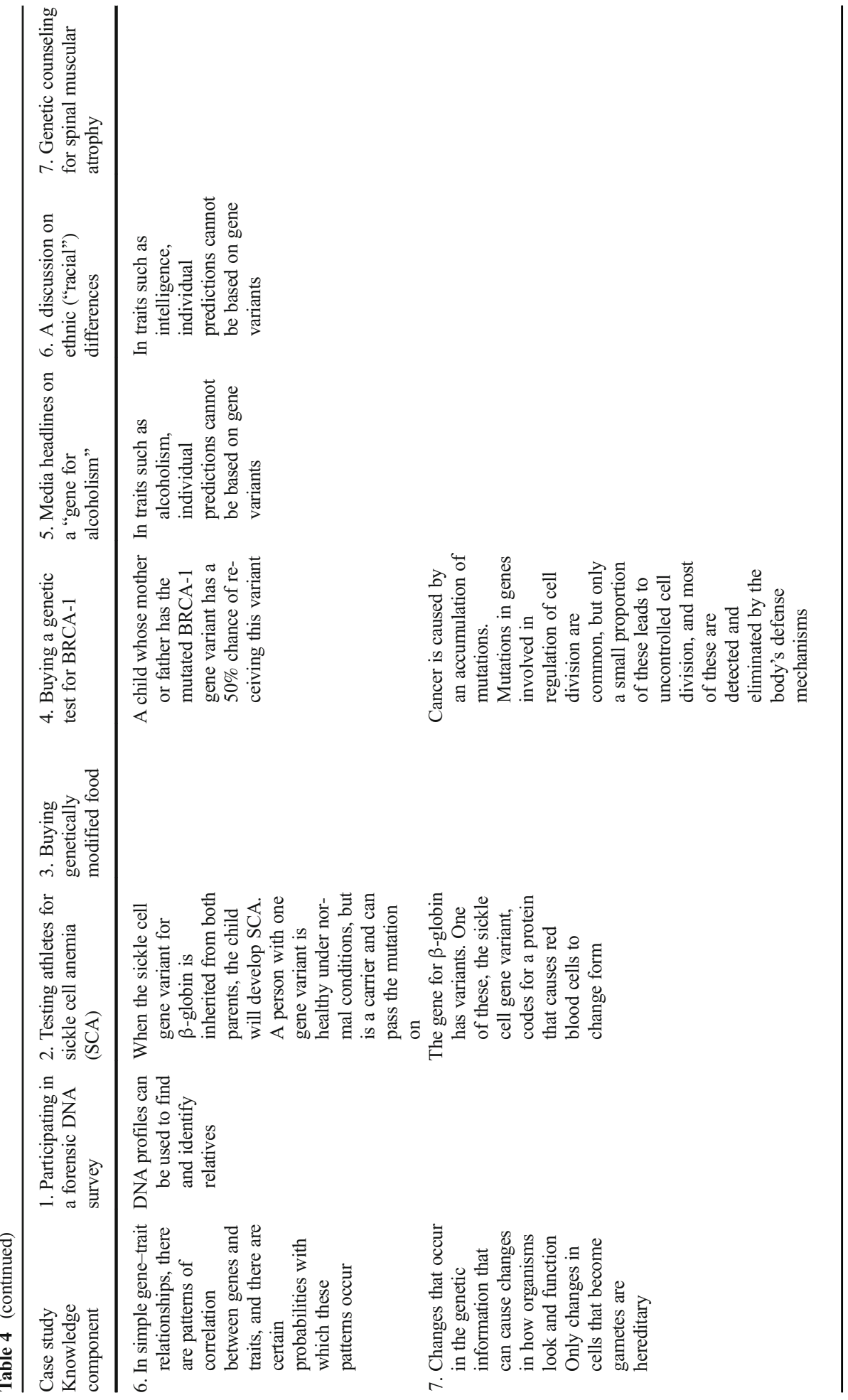




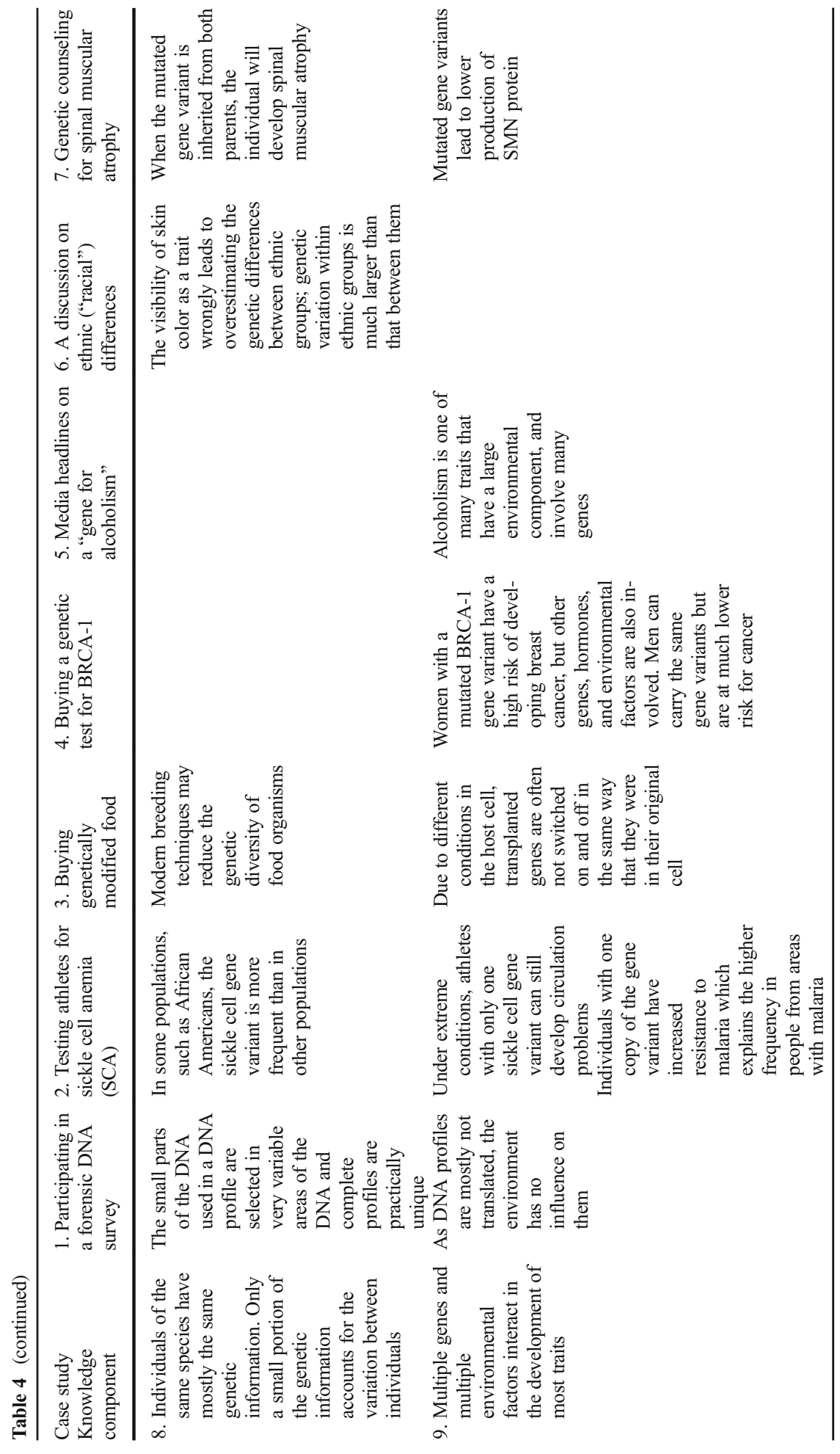




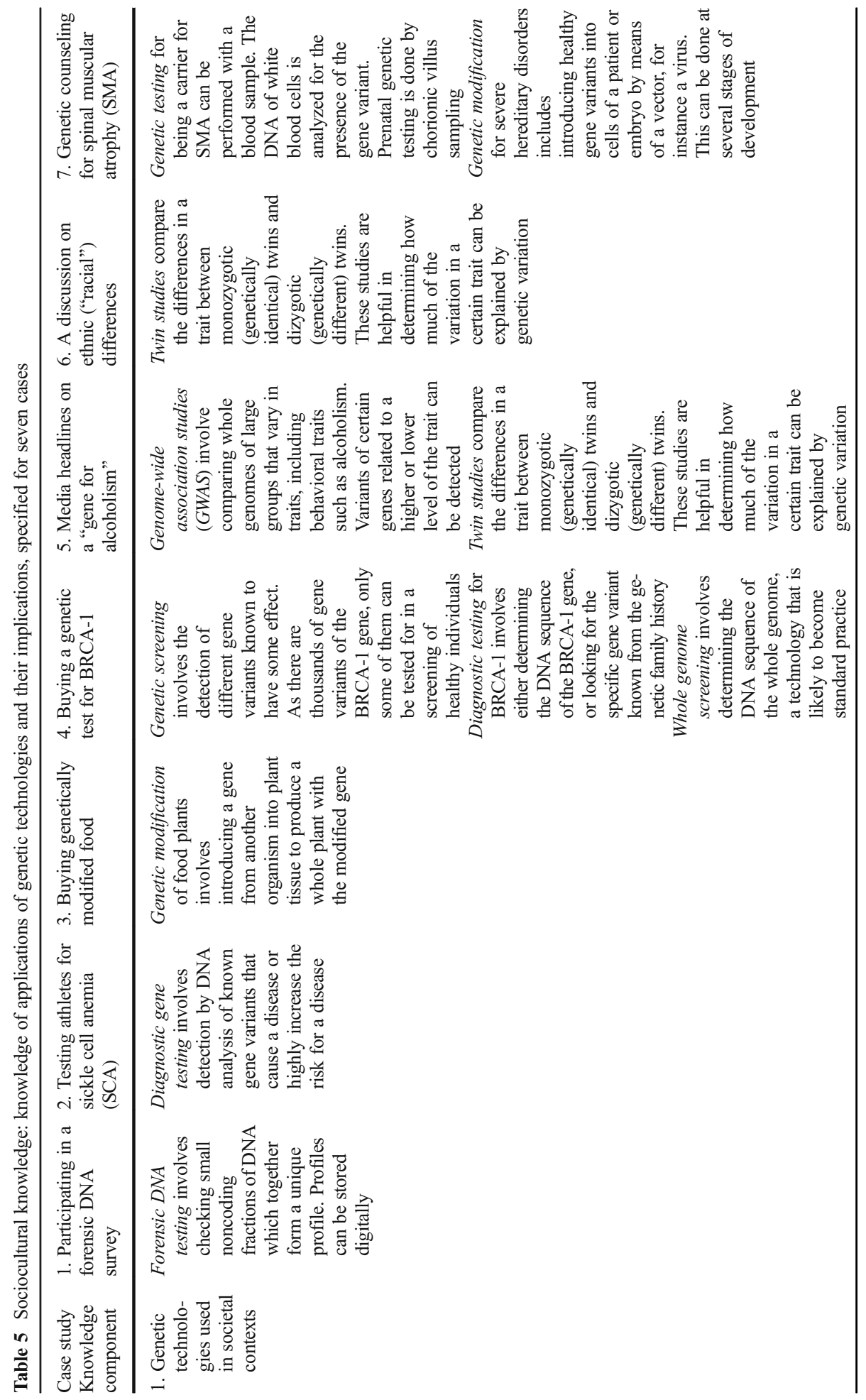




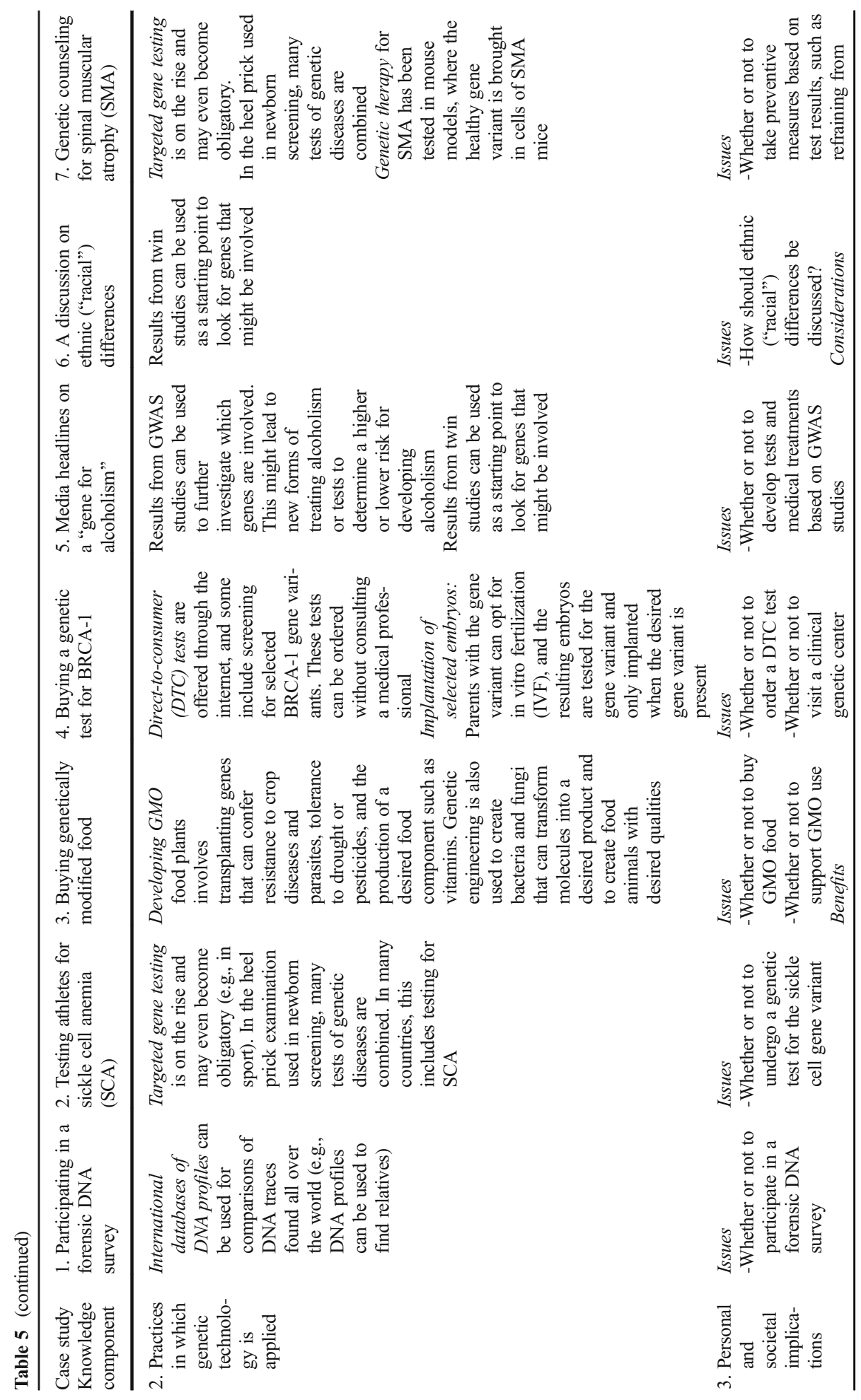




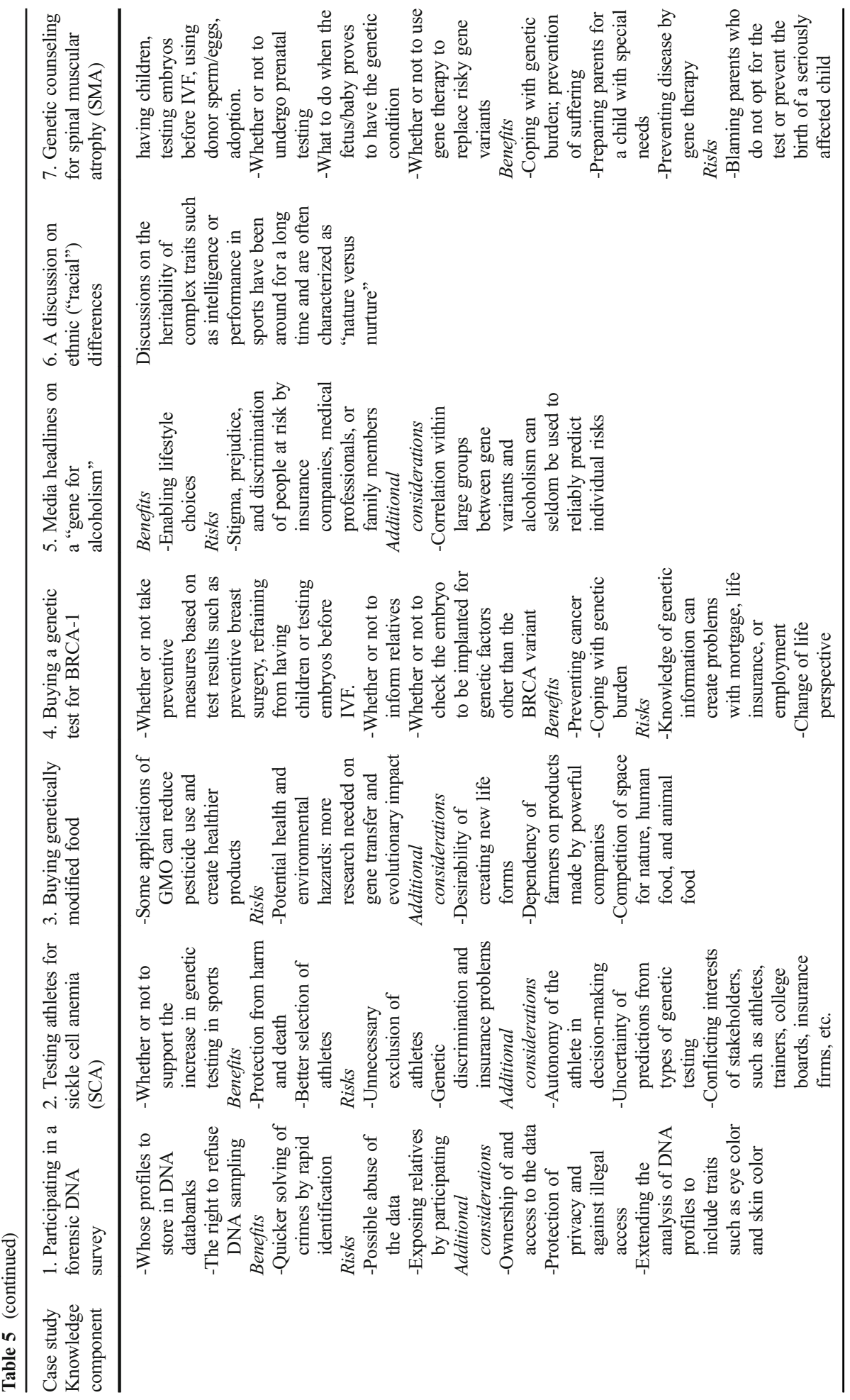




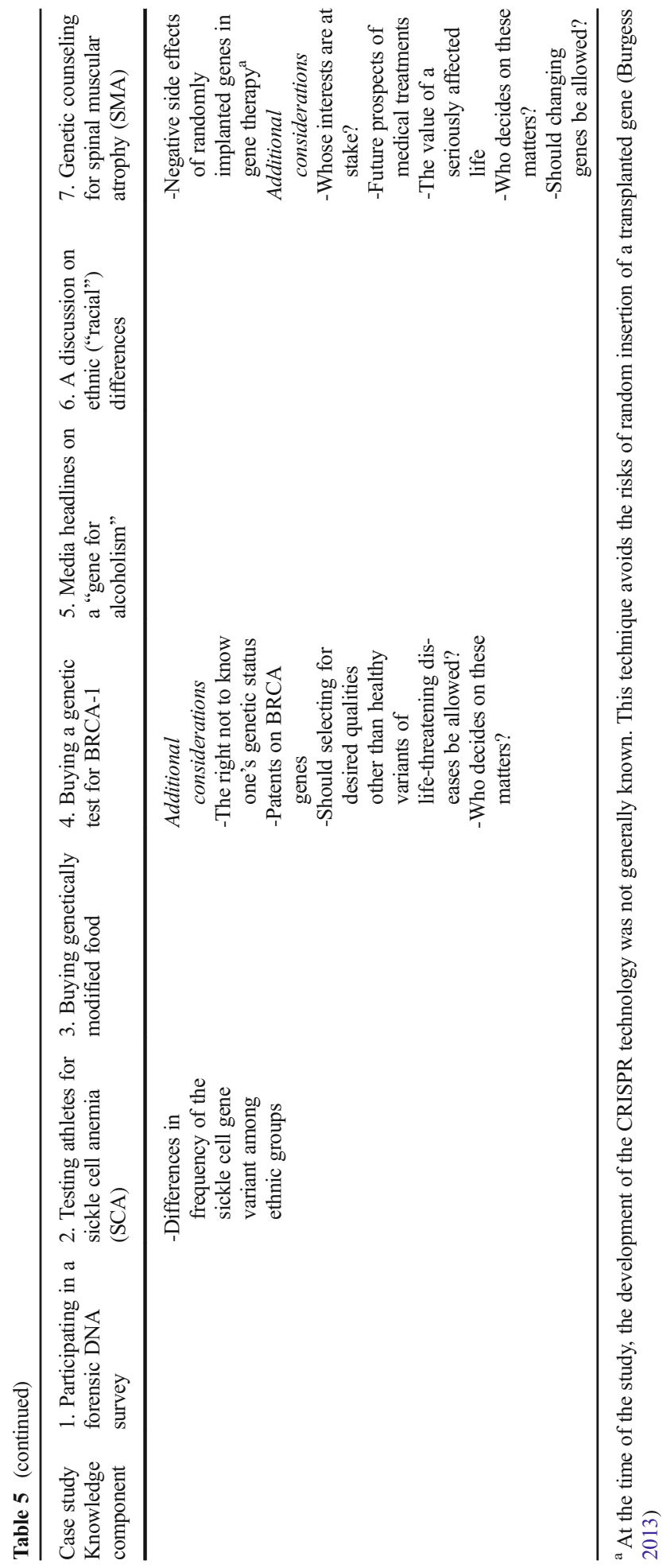




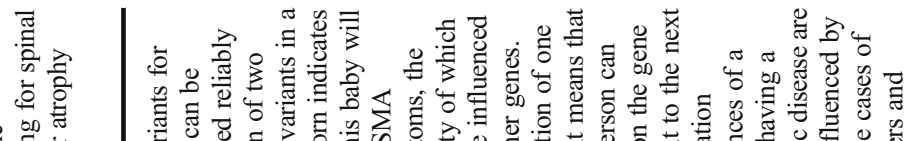
$\begin{array}{lll}0 & \\ 0\end{array}$

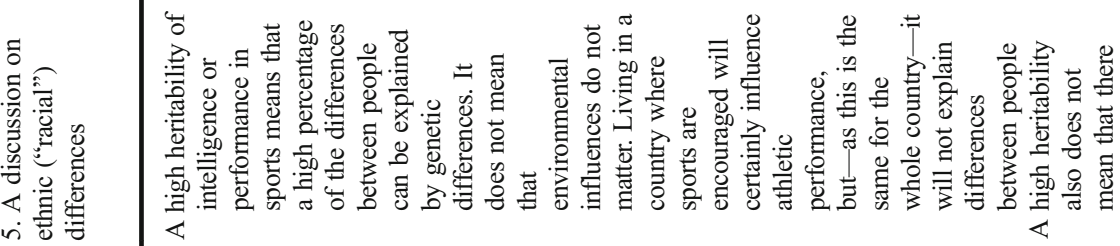

章

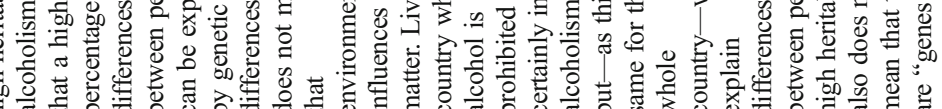

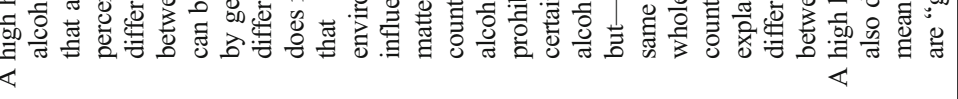

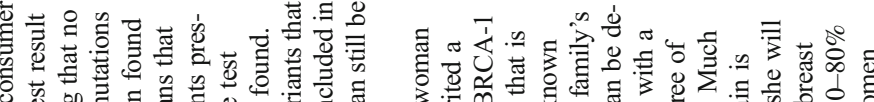

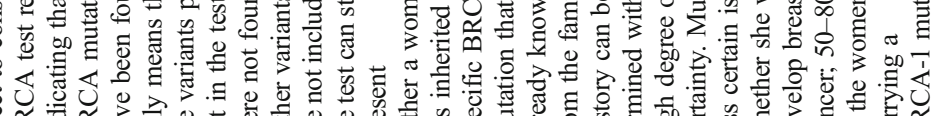

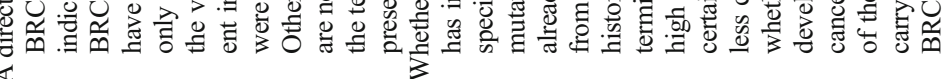

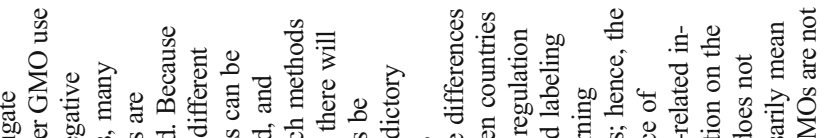

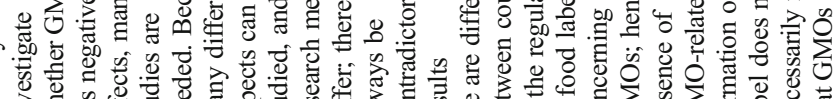
일

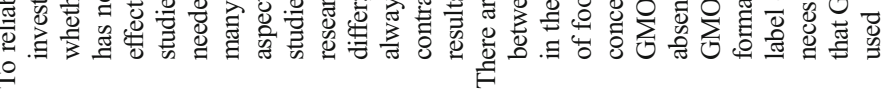
$\ominus$

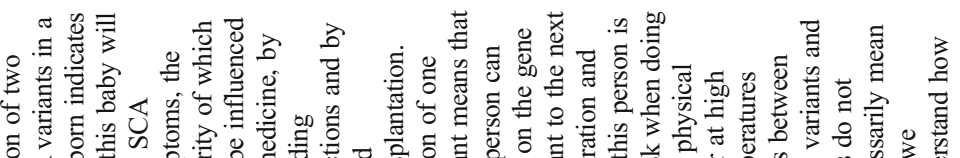
范范等 on

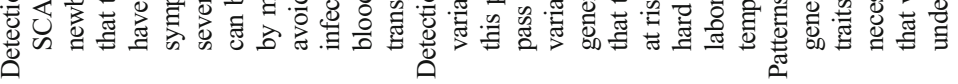
क्ष 


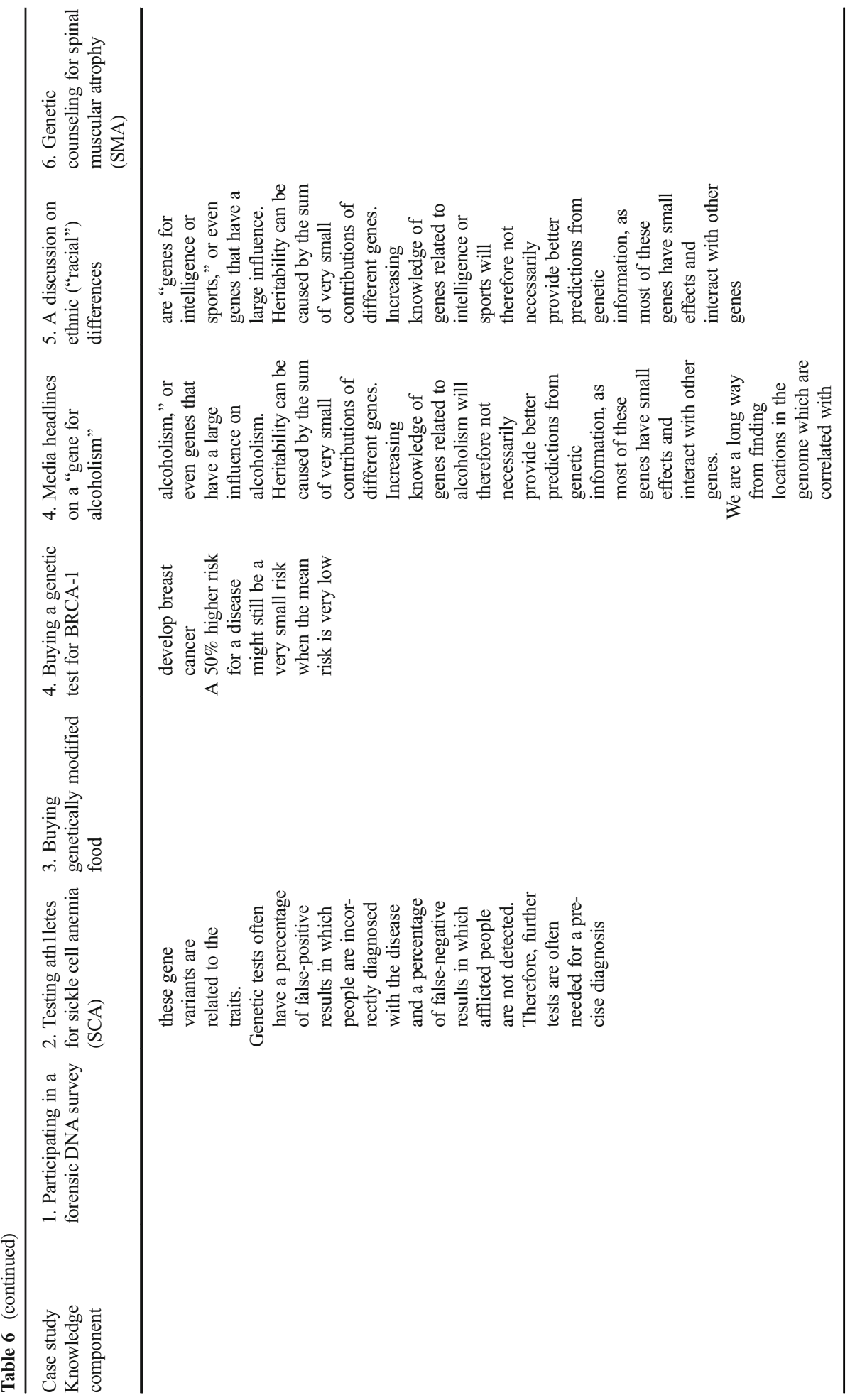




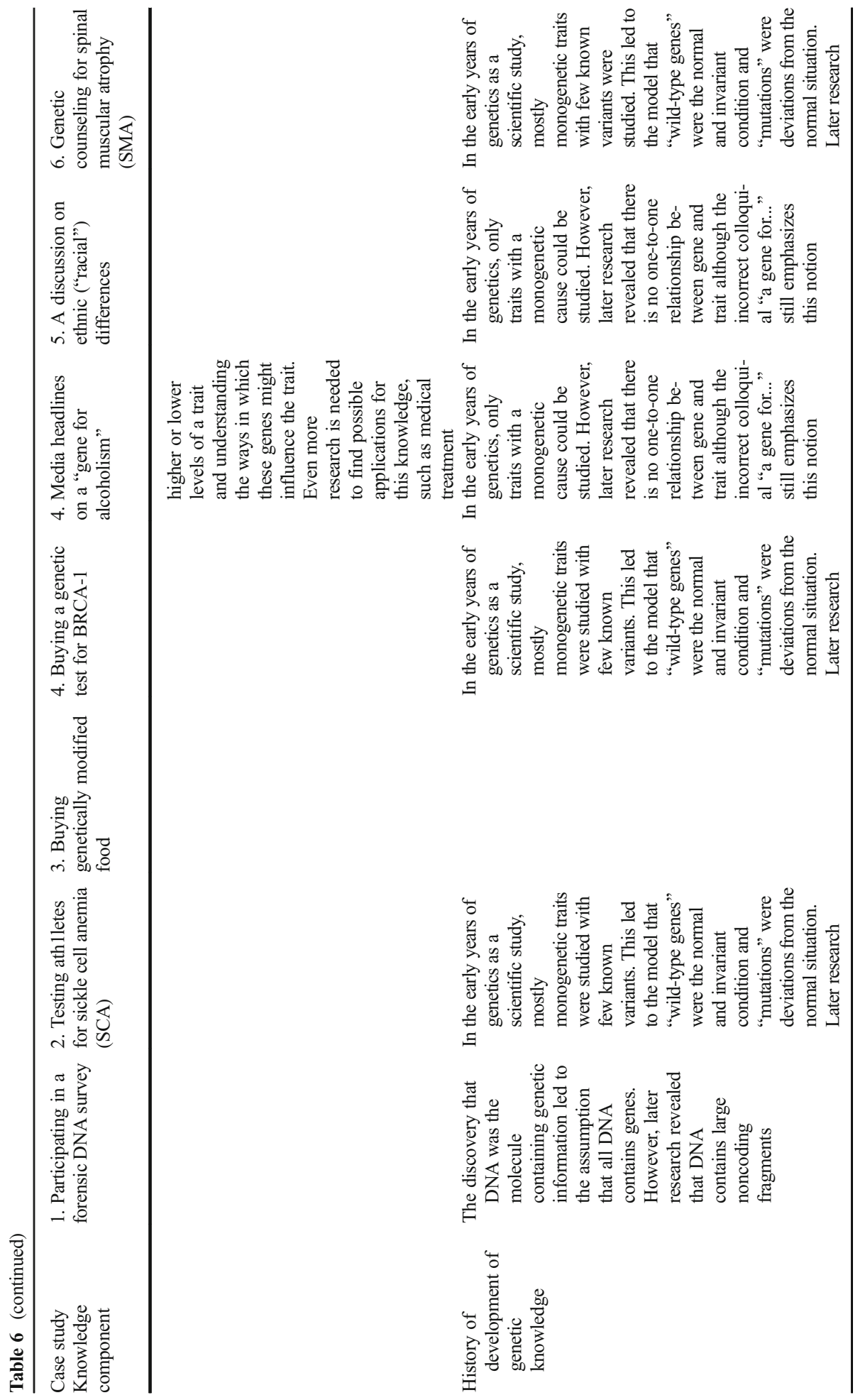




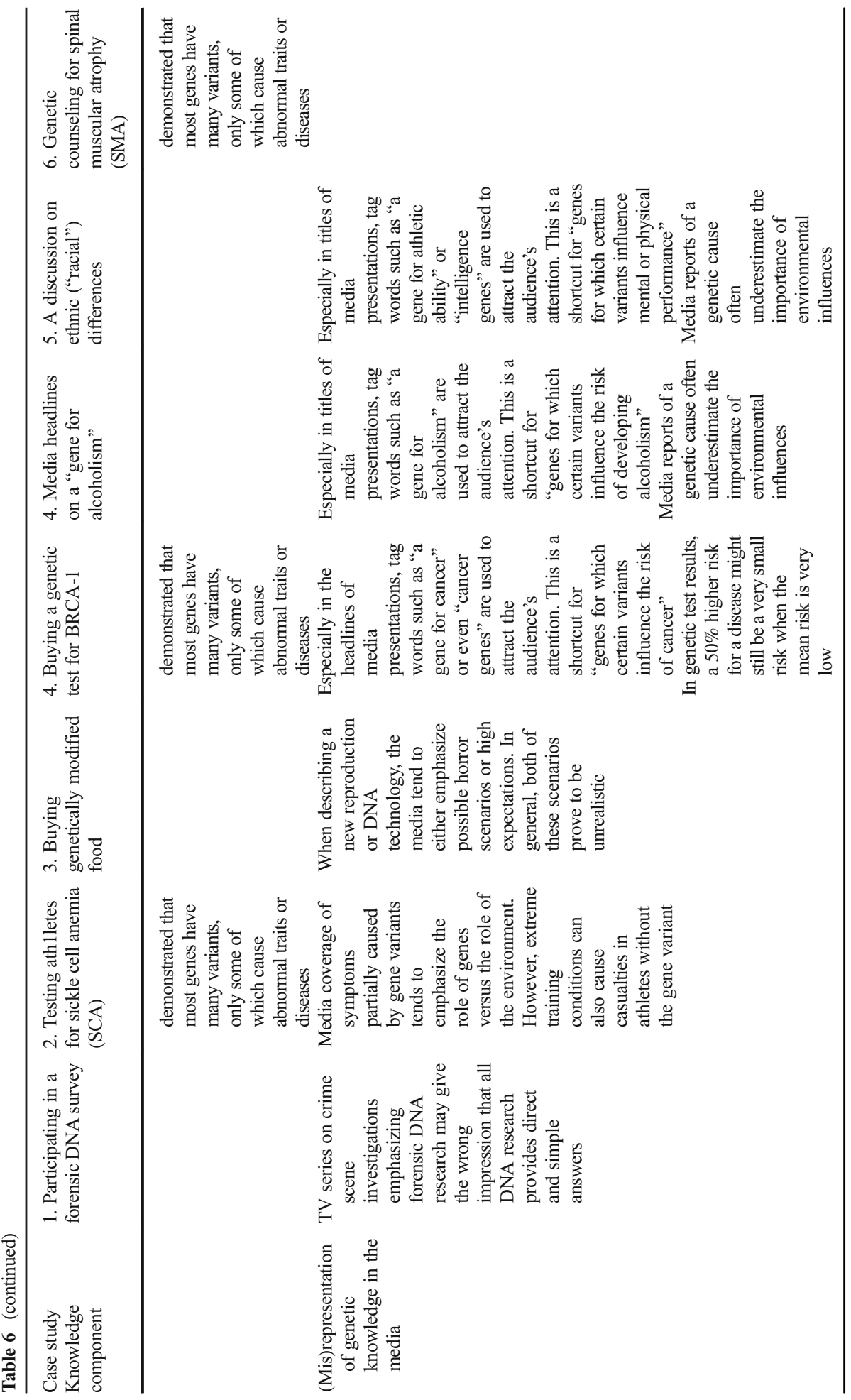




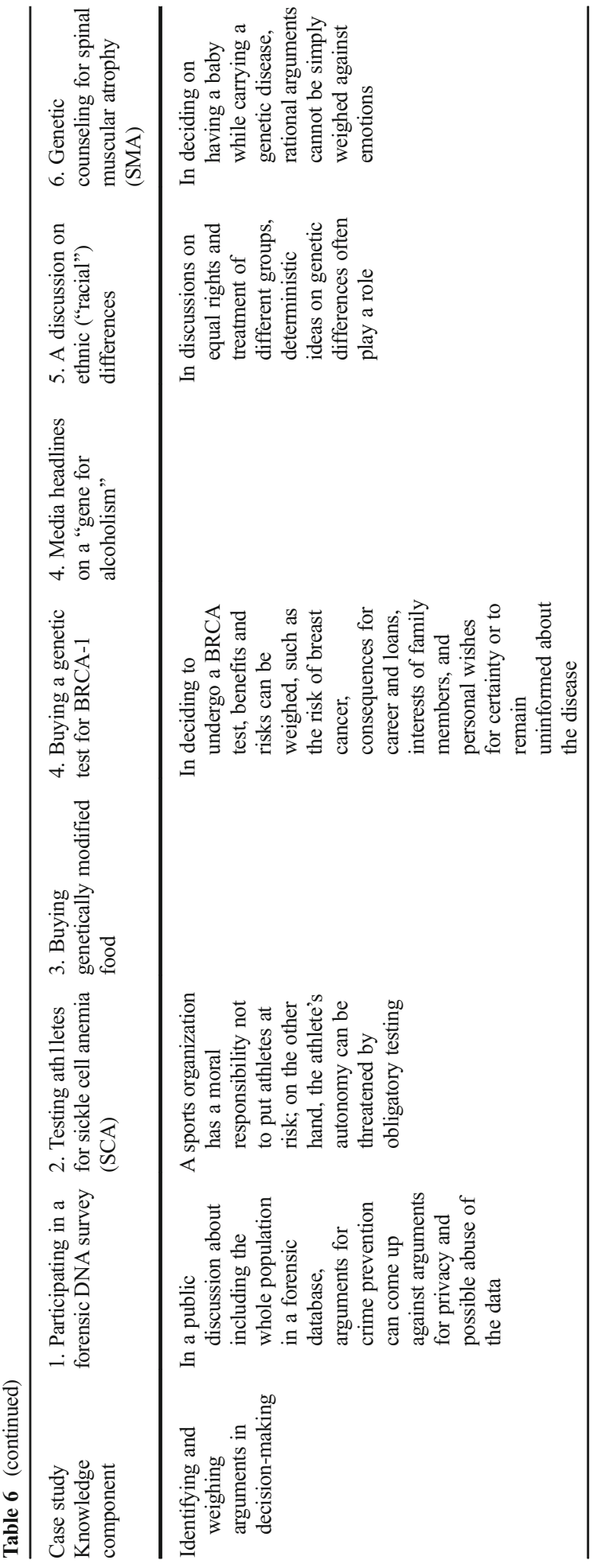


participants could indicate whether they agreed with the formulation of genetic literacy. Apart from some comments on the categorization, all agreed with the formulation.

\section{Results}

\subsection{Categories of Conceptual Knowledge}

After the first phase of the research, three tables were formed, based on the distinction among conceptual, procedural, and epistemic knowledge (OECD 2016). Expert answers on conceptual knowledge could, for the most part, be classified according to the framework of Duncan et al. (2009). Three additional categories (I, J, and K in Table 1) were formed to include answers that did not fit the framework.

Based on the discussions in the second phase and comments by e-mail, the following changes were made in the conceptual knowledge components (Table 1, right column):

- Several knowledge items were redefined to comply with current genetics, and basic concepts such as DNA and gene were included in the description.

- A new category on variation was added (Table 1, category 8), as many answers fell into that category, which was not present as such in the original framework.

- The new category of polygenic inheritance (Table 1, category K) was combined with the existing category of environmental influence (Table 1, category 9): "Multiple genes and multiple environmental factors interact in the development of most traits." This category was considered by several participants as the core message of genetic literacy.

- Evolution and natural selection (Table 1, category J) were omitted from the conceptual knowledge in order to focus the definition of genetic literacy. It proved difficult to decide what to include in genetic literacy, as genetics is linked to other biological phenomena such as evolution and development.

\subsection{Categories of Epistemic, Sociocultural, and Procedural Knowledge}

The analysis of the answers originally classified as epistemic knowledge resulted into a division in two separate types of knowledge. One type deals with how genetic knowledge is used in societal applications and which issues are generated by these applications. This type of knowledge was given the title of sociocultural knowledge (Table 2).

The second type consists of knowledge about how genetic information should be interpreted, both in professional and public communication. This type retained the name epistemic knowledge.

From the answers that were classified as procedural knowledge, two main components emerged during the first phase of the study: (i) science-communication skills and (ii) argumentation and decision-making skills. During the later phases, two kinds of comments gave reason to change this initial classification. One comment was that argumentation should be a part of epistemic knowledge and therefore be transferred from procedural to epistemic knowledge (Table 3). The second comment was that the other elements of procedural knowledge appeared to be general skills, not specific for genetic-related situations. Therefore, specific procedural knowledge was not included as part of genetic literacy. 


\subsection{Outcomes of the Discussion on the Case Studies}

Tables 4, 5, and 6 describe the different types of genetic knowledge needed for decisionmaking in the seven case studies (see descriptions of each case study in Appendix 2). Where no specific genetic knowledge seems to be needed for a case, the cells remain empty. The three knowledge categories can be described as follows:

- Conceptual knowledge: knowledge of genetic concepts.

- Sociocultural knowledge: knowledge of how applications of genetic technologies are used in societal activities and in what ways they influence human lives.

- Epistemic knowledge: knowledge of the meaning of genetic information. This concerns the knowledge needed to interpret genetic information from different sources and how to use these in argument and decision-making. This knowledge includes Nature of Science aspects such as the certainty and uncertainty of genetic information and how genetic concepts have evolved.

In Tables 4, 5, and 6, the different types of knowledge are described in relation to situations in which this knowledge has to be applied in personal or societal decision-making on geneticrelated issues.

\section{Conclusions}

Based on the results, according to the participants of this study, the following answer can be given to the research question "which genetic knowledge is needed for decision-making on genetic-related issues?." Genetic literacy can be described by the three aforementioned types of knowledge, with the knowledge components presented in Tables 1, 2, and 3.

Starting with sociocultural knowledge, the results indicated that genetic literacy includes awareness of the fact that new genetic technologies are frequently used in practices that can affect everyone, such as medical diagnosis and therapy, food production, and forensics, and that most of these applications have benefits as well as risks or disadvantages, for individuals and for groups, which makes careful decision-making both complex and necessary. The cases illustrated that decision-making on these issues requires knowledge of certain (more or less case-specific) genetic concepts, together with an understanding of the meaning of genetic information and the misleading way in which this information sometimes reaches the public. For example, a focus on the Mendelian inheritance model, whereby one allele leads to a specific trait without environmental influences, can contribute to a misleading image of most gene-trait relationships. This does not mean that Mendelian inheritance has become obsolete (it is needed to understand certain types of genetic-related issues), but that Mendelian inheritance should be regarded as the exception, not the rule. Many participants indicated that conceptual knowledge component 9 (multiple genes and multiple environmental factors interact in the development of most traits) summarizes the most important message of this study. A similar formulation can be found in the K-12 Framework of the NRC in the part on the core idea LS3: Heredity: Inheritance and Variation of Traits: "Complex relationships between genes and interactions of genes with the environment determine how an organism will develop and function" (NRC 2012, p. 159). The cases demonstrated many examples of obstacles to genetic literacy brought about by transferring the Mendelian inheritance model to 
all gene-trait relationships and by misleading images created by the media. Table 7 summarizes some of these images, which biology education should avoid or correct using the genetic literacy elements described in this article.

\section{Discussion}

The distinction in this framework between conceptual, sociocultural, and epistemic knowledge fits well with the experts' answers, as well as with their discussion of the seven cases. This distinction is comparable with the components of genetic literacy for patients and providers described by McInerney (2002): knowledge of genetics, variation, and disease (comparable with conceptual knowledge); ethical, legal, and social issues (comparable with sociocultural knowledge); and knowledge on the Nature of Science (comparable with epistemic knowledge). There are also many parallels between the framework developed in this study and what is written about genetics in the Next Generation Science Standards (NGSS). The standards are based on the framework K-12 in which disciplinary core ideas, practices, and crosscutting concepts are formulated (NRC 2012). In the NGSS, these elements are integrated in required performances such as the following (aimed for middle school students who learn genetics): "Gather and synthesize information about technologies that have changed the way humans influence the inheritance of desired traits in organisms" (NGSS Lead States 2013). This performance includes knowledge about traits, about genetic applications, and about obtaining and evaluating information. As in the genetic literacy framework presented here, genetic education according to the NGSS is not limited to learning core concepts, but is linked to learning about engineering, technology, and various applications of science (as in the sociocultural knowledge components in our framework) and to the nature of science (as in the epistemic knowledge components in our framework). The importance of the genetic literacy framework presented here lies in the case

Table 7 Examples of misleading images of gene-trait relationships to be replaced by the genetic literacy proposed in this article

\section{Misleading image of gene-trait relations $\quad$ To be replaced by knowledge components of genetic literacy}

Genes have a specific function at the organism level
(as in the expression "a gene for...")

Some genes cause diseases

Genetic traits are only influenced by genes

Organisms have a healthy "wild-type" genotype, from which deleterious mutations form a deviation

DNA research leads to rapid and certain conclusions (such as in crime scene investigation television series)
Genes have functions in cells. Almost no trait can be directly linked to the activity of one gene. The activities of many genes and environmental factors together influence most traits

Genes related to disease have normal functions in the cell but have variants which increase the risk of a disease or behavior

The development of all traits (even monogenetic ones) needs factors from the environment. For some traits, the variation is mainly caused by different gene variants

Many genes have variants, which is the source of adaptation to different circumstances. Some variants can impose a higher risk of disease, depending on the presence of other gene variants, as well as on environmental factors

Most predictions based on gene variants will remain uncertain due to the complex gene-trait relationships 
studies which indicate which specific genetic knowledge is needed and used in a special situation and indicate which choices can be made, with the risk and benefits of each decision.

This article describes a consensus reaching process. Consensus is a relative notion, because approving this final text does not mean that there is a consensus on all matters. The main points of this discussion concern the limits and purpose of genetic literacy.

\subsection{The Limits of Genetic Literacy}

The participants' opinions differed on whether procedural knowledge should be included. The procedural knowledge appeared, for the most part, to be of a general kind, and after some debate, we decided not to include this type of knowledge in our definition of genetic literacy. Without communication skills, however, a twenty-first-century citizen would probably be unable to put genetic knowledge to use in a societal context.

Another topic about which participants disagreed was whether natural selection should be a part of genetic literacy. We decided not to include evolution and natural selection, as many other core biological ideas are also linked to genetic concepts, and including them would result in expansion of the description of genetic literacy to the whole of biology. This distinction is in line with the NRC framework for K-12 science education (NRC 2012), which lists four core ideas that represent basic fields of investigation in the life sciences, among which heredity and evolution appear as two separate core ideas. Nevertheless, separating genetic literacy from evolution literacy seemed odd to some participants of this study, since for decision-making on the use of antibiotics, knowledge on mutation and variation (as included in this article) cannot be separated from knowledge about selection.

\subsection{The Purpose of Genetic Literacy}

Another point of discussion among the participants concerned the purpose of genetic literacy. The methodology that was chosen framed the results in several ways. The question of defining the genetic knowledge that a citizen needs already implied a focus on the knowledge needed in societal contexts and for decision-making. Therefore, using the case studies to discuss genetic literacy implied a "filter" through which genetic knowledge was selected. Some participants wanted to go even further to create an antidote to racist policies, meaning that genetic literacy should also inform certain societal choices. Others thought that the goal of informed decisionmaking is too narrow and that education also has the broader task of introducing students to the cultural heritage of which genetic science is a part. Thus, the procedure of selecting genetic knowledge through the filter of societal cases could exclude genetic knowledge that is needed for goals other than informed decision-making. There were also doubts as to whether the genetic literacy goal of keeping students up to date is feasible, given the speed of the developments in science; it was suggested that it would be more realistic to concentrate on generative and powerful knowledge of core ideas and a critical stance toward the presentation of genetic information.

\subsection{Limitations of the Study}

In a traditional Delphi approach, the participants remain anonymous and interact in writing (Osborne et al. 2003; Bolte 2008). In our study, participants also met each other in person and 
participated in group discussions during the workshop that took place in phase II of the study, so as to promote a deeper understanding of what genetic literacy should entail. The group members were not asked to reach a consensus, but to generate informed and reviewed opinions. Comments before and after the workshop were analyzed and presented anonymously. Almost all of the participants were from countries with comparable social and scientific characteristics. There were no representatives of African or South American countries, where the problems related to genetics can be different. Input from these countries might have influenced the outcomes.

\subsection{Implications of the Study}

Having produced these tables, the next step was to determine what they say about the genetic literacy required by a twenty-first-century citizen. The framework describes both familiar and new elements of genetic education. Familiar elements include knowledge that genetic information is inherited from both parents with basic patterns of Mendelian inheritance (needed, for example, to understand concepts such as carrier and risk in genetic counseling). Elements that receive much more attention in this framework than in traditional genetic education are the complex relationships between genes, environment, and traits, including the concept of heritability (needed, for example, to detect incorrect wording in media reports such as "gene for" (Dupré 2012). The framework does not elaborate specifically on mechanisms such as transcription and meiosis. Namely, knowing that "different genes are switched on and off in different cells" and that "each parent contributes a set of genes, leading to a double set in the offspring" (components 4 and 5, Table 1), is sufficient for a twenty-first-century citizen confronted with genetic-related issues, while knowledge about the specific mechanisms governing these facts is not. Thus, it is proposed that the meiotic model suggested by Stewart et al. (2005), which emphasized the cellular processes underlying gene recombination, sorting, and transfer from one generation to the next, should be acquired during advanced courses in genetics, but is not required for every citizen.

The genetic literacy described in this study can have several functions in education, both at the curriculum level and in the preparation of biology teachers. As a basis for curriculum innovation, genetic literacy is described here as a conceptual framework, not a definition. The framework can consider several cases, making comparisons between cases easy and giving a more complete image of the role of genetics in society. The structure of the framework makes it easy to add new elements, as well as to explore new cases. For example, a new application that occurs in the media can be explored by creating a new case column, specifying the relevant knowledge using the knowledge components of the tables, and comparing the results with those of already described cases. The consequences of a new technology such as CRISPR-Cas (Burgess 2013) can be studied by checking how this would influence benefits and risks in Table 5. The produced framework for genetic literacy is therefore an open one that allows for curricular discussion, revision, and extension.

With regards to the preparation of biology teachers, the framework presented here can also help teachers and teacher trainers to analyze genetic issues that are relevant for their students by using the extensive overview in this framework of genetic technologies, their applications, and the issues that they generate. This may enable the development of educational activities within context-based education and the guidance of classroom discussions on these issues. Communication and argumentation skills are essential for citizenship education, and biology 
teacher education should prepare teachers for discussions on moral issues generated by genetic technologies (Van der Zande et al. 2009). Finally, the framework may also help to improve biology teacher education by pointing out common misconceptions.

Although this is all very challenging for science teachers, many examples of context-based genetic education already exist. In using contexts such as the seven described cases in biology education, the different types of knowledge can be distinguished but should not be treated separately. Discussing a new application of genetic technology can generate a need for new conceptual knowledge as well as stimulate discussion regarding its advantages and disadvantages.

Special attention should be paid to developing skills for taking uncertainty into account. The combination of more genetic information reaching us with less certain predictions makes the task of preparing students for citizenship difficult. McInerney (2002) mentioned the "management of uncertainty" as a fundamental part of genetic literacy. Teachers might have to elaborate on different sources of uncertainty, for example, uncertainty stemming from the complexity of the gene-environment-trait interplay, uncertainty caused by the meiotic process leading to different genotypes, and uncertainty caused by a technology that has false-positive and false-negative outcomes. The risk of overstating this uncertainty is that it might lead to rejection of all scientific information.

Another topic that needs careful treatment involves the concepts of race and ethnicity (Donovan 2016). Obvious visible differences such as skin color and results of sport events such as marathon running might easily lead students to the idea that important genetic differences exist between groups of people. The issue is complicated by the difference between sociological and biological meanings of race and the political issues related to them. This explains why this topic is often avoided in education. However, careful training in argumentation can prepare students for discussions on this topic (Puig and JiménezAleixandre 2011).

We feel that the reported procedure for defining genetic literacy, i.e., defining the conceptual core and analyzing cases in which specific knowledge is needed, could also be used for other science topics which are linked to important societal implications.

Acknowledgments The participants in this study are named in Appendix 1. We thank them all for providing the elements from which this study was constructed and for participating in productive discussions.

Funding information This study was made possible by generous financial support from the Cancer Genomics Centre, part of the Netherlands Genomics Initiative.

Conflict of interest There was no conflict of interest in this study.

\section{Appendix 1. Participants in the study}

Tuomas Aivelo, Department of Teacher Education, University of Helsinki, Finland; Pamela Black Education Development Officer, Wellcome Genome Campus Cambridge, UK; Mark Bloom, Science Educator at Biology Sciences Curriculum Studies, USA; Dirk Jan Boerwinkel, Freudenthal Institute for Science and Mathematics Education, Utrecht University, the Netherlands; Rebecca Carver Bruu, Department of Communication, Norwegian Institute of Public Health, Norway; Umran Betul Cebesoy Middle East Technical University, Turkey; 
Nina Christenson Teacher trainer and researcher at Karlstad University, Sweden; Paul Davies, Teacher trainer, Institute of Education (IOE) University of London, UK; Vaille Dawson, Professor Science and Mathematics Education Curtin University Perth Australia; Michael Dougherty, Director of Education American Society of Human Genetics, USA; Ravit Golan Duncan Associate Professor of Science Education Rutgers, The State University of New Jersey, USA; John Dupre Philosophy of Science Univ. of Exeter, Director of Egenis Centre for Genomics in Society, UK; Maria Joao Fonseca Researcher University of Porto, Portugal; Niklas Gericke Senior Lecturer in Biology Education Karlstad University Sweden; Judith Halper Weizmann Institute Rehovot Israel; Matt Hickman Education Project Manager Nowgen UK; Corina Hoessle Group leader AG Biologiedidaktik Carl von Ossietzky Universität Oldenburg, Germany; Mona Holmqvist Associate Professor University of Gothenburg, Sweden; Isa Houwink Researcher VU Medical Center Division of Community Genetics Amsterdam, the Netherlands; Kaisa Immonen-Charalambous Kaisa Senior Policy Adviser European Patients' Forum, Belgium; Annie Jamieson Religion and History of Science University of Leeds, UK; John Jungck University of Delaware, USA; Marianna Kalaitsidaki Assistant Professor at the Department of Primary Education of the University of Crete, Greece; Marie Christine Knippels, Researcher at Freudenthal Institute for Sc\&M Ed., Utrecht, the Netherlands; Ralph Levinson Researcher ScEd at Institute of Education London University, UK; Jenny Lewis Former Director, Centre for Studies in Science and Mathematics Education University of Leeds, UK; Chen-yung Lin Professor, Graduate Institute of Science Education, National Taiwan Normal University, Taiwan; Amelie Lipp Teacher Trainer at Universite de Toulouse, France; François Lombard Biology Education, Université de Genève, IUFE, Switzerland; Brian McDonald DNA Consults Lindfield Australia; Sylvia Metcalfe Professor in Medical Genetics, Department of Pediatrics, The University of Melbourne Australia; Dave Micklos Executive Director the DNA Learning Center, USA; Maureen Munn Outreach Program for High School Teachers and Students at the University of Washington, USA; Miranda Overbeek Junior College Utrecht, ECENT Expertise Center for Science Teacher Trainers Utrecht the Netherlands; Tessel Rigter VU University Medical Center (VUmc), Department of Clinical Genetics, Section of Community Genetics, EMGO Institute for Health and Care Research, the Netherlands; Aaron Rogat Research Scientist Educational Testing Service Princeton, New Jersey, USA; Ronit Rozenszajn Biology Teacher and Teacher Trainer, Israel; Ragna Senf Coordinator Mobile DNA Lab UMC, Utrecht, the Netherlands; Kateryna Shavanova National University of Life and Environmental Sciences of Ukraine, Ukraine; Merav Siani PhD Student Dept. of Sc. \& Techn. Education Ben Gurion University, Israel; Laurence Simonneaux Professor of Science Education Ecole Nationale de Formation Agronomique Université de Toulouse, France; Hienke Sminia Developer Mobile DNA Lab on Bioinformatics at Netherlands Bioinformatics Centre, Nijmegen, the Netherlands; Michelle Smith Assistant Professor, School of Biology and Ecology, and Research in STEM Education Center, University of Maine, USA; Mike Smith Professor of Medical Education Mercer University School of Medicine Macon, USA; Louisa Stark Director, Genetic Science Learning Center, The University of Utah, USA; Bella Starling Researcher at Nowgen, UK; Karina Thorne Researcher at Karlstad University Sweden; Cecile Titelein Veterinarian and Farmers Cooperation Representative, France; Marc van Mil Developer at UMC, Utrecht, the Netherlands; Wilhelmina van Rooy Senior Lecturer and Teacher Trainer Science Learning and Teaching School of Education, Australian Catholic University, Australia; Paul van der Zande Teacher Trainer and Researcher Utrecht University, the Netherlands; Arend Jan Waarlo, Freudenthal Institute for Science and Mathematics Education, Utrecht University, the 
Netherlands; Horst Wolter Developer at Freudenthal Institute for Sc\&M Ed., Utrecht, the Netherlands; Ting Wu Director Personal Genetics Education Project Boston, USA; Anat Yarden, Weizmann Institute of Science, Rehovot, Israel

\section{Appendix 2. Description of the seven cases used in the conference}

1. Participating in a forensic survey

You are asked to participate in a forensic DNA survey to solve a crime in the neighborhood. (This case is based on a true story from 2012 about solving the murder of a Dutch girl 13 years earlier.)

http://www.councilforresponsiblegenetics.org/blog/post/Should-feds-adopt-a-DNAprogram-that-cracked-a-1999-Dutch-murder-case.aspx

2. Testing athletes for sickle cell anemia

You want to participate in a sport at a competitive level, and are asked to undergo a test to determine genetic risk factors. (This case is also based on a true story about testing college athletes in the USA for sickle cell trait after the death of an athlete carrying the trait and the subsequent lawsuit.)

https://www.insidehighered.com/views/2013/01/18/testing-sickle-cell-trait-athletes-unwise-essay

3. Buying genetically modified food

You have the choice in a supermarket of buying products made with genetically modified organisms (GMOs). (The discussion concerning GMOs already has a long history and is far from resolved, which makes it an important but difficult topic to discuss in education.)

http://www.ecowatch.com/its-official-19-european-countries-say-no-to-gmos-1882106434.html

4. Buying a "direct-to-consumer" genetic test for BRCA-1

You are considering buying a BRCA test through a commercial website. As you have a familial history of breast cancer, you have doubts about ordering this test. (Direct-to-consumer tests offer screening for some gene variants related to disease outside the medical circuit.)

http:/www.fda.gov/NewsEvents/Newsroom/PressAnnouncements/ucm435003.htm

5. Discussing media headlines on a newly found "gene for alcoholism"

You read a media headline on a newly discovered "gene for alcoholism" and wonder whether this could be important for you as alcoholism runs in your family. (Many media headlines reporting genetic studies still contain "gene for...," implying that the found gene variant contributes importantly to the risk.)

http://www.niaaa.nih.gov/alcohol-health/overview-alcohol-consumption/alcohol-usedisorders/genetics-alcohol-use-disorders

6. Participating in a discussion on ethnic ("racial") differences 
During a social meeting, you hear someone claiming "of course races differ in IQ. IQ has proven to be largely genetically determined and anyone can see that races differ. Just look at the Olympics, and which countries always win the marathon." How do you react?

http://www.runnersworld.com/peak-performance/why-are-kenyan-distance-runners-so-fast

\section{Genetic counseling for spinal muscular atrophy}

A healthy couple who want a child undergo a reproductive carrier screen. The test shows that both are carriers for spinal muscular atrophy (SMA), a disease in which muscles progressively deteriorate, often in early infan84cy. The couple is deliberating about whether they should have a child, knowing their genetic condition.

http://ghr.nlm.nih.gov/condition/spinal-muscular-atrophy

Open Access This article is distributed under the terms of the Creative Commons Attribution 4.0 International License (http://creativecommons.org/licenses/by/4.0/), which permits unrestricted use, distribution, and reproduction in any medium, provided you give appropriate credit to the original author(s) and the source, provide a link to the Creative Commons license, and indicate if changes were made.

\section{References}

Bolte, C. (2008). A conceptual framework for the enhancement of popularity and relevance of science education for scientific literacy, based on stakeholders' views by means of a curricular Delphi study in chemistry. Science Education International, 19, 331-350.

Bowling, B. V., Huether, C. A., Wang, L., Myers, M. F., Markle, G. C., \& Dean, G. E. (2008). Genetics literacy of undergraduate non-science majors and the impact of introductory biology and genetics courses. Bioscience, 58, 654-660.

Burgess, D. J. (2013). Technology: a CRISPR genome-editing tool. Nature Reviews Genetics, 14, 80-81.

Campbell, A. M., Zanta, C. A., Heyer, L. J., Kittinger, B., Gabric, K. M., \& Adler, L. (2006). DNA microarray wet lab simulation brings genomics into the high school curriculum. CBE Life Sciences Education, 5, 332339.

Christensen, K. D., Jayaratne, T. E., Roberts, J. S., Kardia, S. L. R., \& Petty, E. M. (2010). Understandings of basic genetics in the United States: results from a national survey of black and white men and women. Public Health Genomics, 13, 467-476.

Donovan, B. M. (2016). Framing the genetics curriculum for social justice: an experimental exploration of how the biology curriculum influences beliefs about racial difference. Science Education, 100, 586616.

Dougherty, M. J. (2009). Closing the gap: inverting the genetics curriculum to ensure an informed public. The American Journal of Human Genetics, 85, 6-12.

Dougherty, M. J., Pleasants, C., Solow, L., Wong, A., \& Zhang, H. (2011). A comprehensive analysis of high school genetics standards: are states keeping pace with modern genetics? CBE Life Sciences Education, 10, $318-327$.

Dupré, J. (2012). Processes of life. Essays in the philosophy of biology. Oxford: Oxford University Press.

Duncan, R. G., Rogat, A., \& Yarden, A. (2009). A learning progression for deepening students' understandings of modern genetics across the $5^{\text {th }}-10^{\text {th }}$ grades. Journal of Research in Science Teaching, 46, 655-674.

Gelbart, M. E. (2012). Catching education up with technology: preparing the public to make informed choices about personal genetics. CBE Life Sciences Education, 11, 1-2.

Houwink, E. J. F., Henneman, L., Westerneng, M., van Luijk, S. J., Cornel, M. C., Dinant, J. G., \& van der Vleuten, C. (2012). Prioritization of future genetics education for general practitioners: a Delphi study. Genetics in Medicine, 14, 323-329.

Jennings, B. (2004). Genetic literacy and citizenship: possibilities for deliberative democratic policymaking in science and medicine. The Good Society, 13, 38-44.

Kaye, C., \& Korf, B. (2013). Genetics literacy and competency. Pediatrics, 132, 224-230.

Laugksch, R. (2000). Scientific literacy: a conceptual overview. Science and Education, 71, 117-134. 
Machluf, Y., \& Yarden, A. (2013). Integrating bioinformatics into senior high school: design principles and implications. Briefings in Bioinformatics, 14(5), 648-660.

McInerney, J. D. (2002). Education in a genomic world. Journal of Medicine and Philosophy, 27, 369-390.

National Research Council [NRC]. (2012). A framework for K-12 science education: practices, crosscutting concepts, and Core ideas. Washington, D.C: The National Academies Press.

NGSS Lead States. (2013). Next generation science standards: for states, by states. Washington, DC: The National Academies Press.

OECD (2016). "PISA 2015 Science Framework", in PISA 2015 Assessment and Analytical Framework: Science, Reading, Mathematic and Financial Literacy. Paris: OECD Publishing.

Osborne, J., Collins, S., Ratcliffe, M., Millar, R., \& Duschl, R. (2003). What "ideas-about-science" should be taught in school science? A Delphi study of the expert community. Journal of Research in Science Teaching, $40,692-720$.

Pearson, Y. E., \& Liu-Thompkins, Y. (2012). Consuming direct-to-consumer genetic tests: the role of genetics literacy and knowledge calibration. Journal of Public Policy \& Marketing: Spring, 2012(31), $42-57$.

Puig, B., \& Jiménez-Aleixandre, M. P. (2011). Different music to the same score: teaching about genes, environment and human performances. In T. Sadler (Ed.), Socio-scientific Issues in the Classroom: Teaching, Learning and Research. Dordrecht: Springer.

Shamos, M. H. (1995). The myth of scientific literacy. New Brunswick: Rutgers University Press.

Stewart, J., Cartier, J. L., \& Passmore, C. M. (2005). Developing understanding through model-based inquiry. In How Students Learn: Science in the Classroom (pp. 515-565). Washington DC: The National Academies Press.

Van der Zande, P., Brekelmans, M., Vermunt, J. D., \& Waarlo, A. J. (2009). Moral reasoning in genetics education. Journal of Biological Education, 44(1), 31-36.

Van Mil, M. H., Boerwinkel, D. J., Buizer-Voskamp, J. E., Speksnijder, A., \& Waarlo, A. J. (2010). Genomics education in practice: evaluation of a mobile lab design. Biochemistry and Molecular Biology Education, 38(4), 224-229. 